\title{
Estimating Natural Rate of Interest and Equilibrium Exchange Rate: A Case of the Czech Republic
}

\section{Zdeněk Pikhart, ${ }^{1}$ Pavla Froňková ${ }^{2}$}

\begin{abstract}
Article deals with estimating real natural interest rate and exchange rate to construct monetary conditions index suitable for the Czech open economy. Despite unobservable characteristics of underlying interest rates and exchange rate, the importance of reference indicators for monetary policy is crucial. Proposed monetary condition index in gap form examines monetary impulse on economic and credit cycle in inflation targeting model.
\end{abstract}

Keywords: Natural Rate of Interest, Equilibrium Exchange Rate, Monetary Conditions Index

JEL Classification: D53, E43, F31

Received: 25 April 2019 / Accepted: 10 October 2019 / Sent for Publication: 5 December 2019

\section{Introduction}

The assumption of endogenous credit supply under the inflation targeting framework raises the issue of methodological capture of the monetary policy stance. The traditional monetary policy tools are interest rates, and exchange rate and their deviations from equilibrium values create impulse to aggregate demand and thus affect inflation, which is the final goal of the most central banks.

Despite unobservable characteristics of underlying interest rates and exchange rate, the importance of reference indicators for monetary policy is crucial. Therefore this article develops a methodology of estimating real equilibrium interest rates and exchange rate in small open economy to construct main elements of anti-cyclical monetary policy in a model of inflation targeting in small open economies. Proposed monetary condition index in gap form (deviation of exchange rate and interest rates from its underlying

\footnotetext{
${ }^{1}$ University of Economics in Prague, Faculty of Finance and Accounting, W. Churchill Sq.1938/4, 13067 Prague 3 and also Ministry of Finance of the Czech Republic, Department of Economic policy, Macroeconomic Analysis Unit, Letenská 15, 11810 Prague 1, Czech Republic, Zdenek.Pikhart@mfcr.cz.

${ }^{2}$ Ministry of Finance of the Czech Republic, Department of Economic policy, Macroeconomic Analysis Unit, Letenská 15, 11810 Prague 1, Czech Republic, Pavla.Fronkova@mfcr.cz.
}

(C) 2019 by the authors; licensee Review of Economic Perspectives / Národohospodářský obzor, Masaryk University, Faculty of Economics and Administration, Brno, Czech Republic. This article is an open access article distributed under the terms and conditions of the Creative Commons Attribution 3.0 license, Attribution - Non Commercial - No Derivatives. 
values) examines monetary impulse on economic and credit cycle in inflation targeting model.

The first chapter is dedicated to estimating real natural rate of interest in the Czech economy. The methods based on the Taylor rule approach, statistical filtering, and potential output growth are presented all modified for small open economy.

The second chapter deals with the estimate of the equilibrium real exchange rate. The error correction model is applied to Czech data.

The third chapter joins estimates of natural interest rate and equilibrium exchange rate together into monetary condition index capturing overall monetary policy setting in Czech economy.

\section{Real natural rate of interest}

The real natural interest rate is interest rate consistent with an economy in general equilibrium. Wicksell (1898) famously described the natural rate of interest: "There is a certain rate of interest on loans which is neutral in respect to commodity prices, and tends neither to raise nor to lower them." The natural rate of interest can be characterized as the level of the short-run real interest rate that is consistent with output near its potential and stable inflation near its target (Laubach and Williams, 2003). The neutral interest rate is then natural rate of interest plus inflation rate.

To estimate the natural rate of interest, several quantitative methods need to be applied with statistical uncertainty and as a subject of significant ex-post revisions. Taylor (1993), in his Taylor rule introduction, simply assumes real natural interest rate to be stable and around $2 \%$ p. a. But real interest rate may vary over time due to changes in either structural (potential growth, demographics, households time preferences, market structure) or transitory (economic cycle, macroeconomic shocks) economic factors. Changes in structural factors are outside the control of the central bank and normally happen at low frequencies, govern the longer-run trend (Calstrom and Stehulak, 2015). While macro shocks, which occur at higher frequencies (like aggregate demand fluctuations), may temporarily deviate real interest rate from its longer-run trend (Curdia and Tambalotti, 2015) since the central bank adjust interest rates as the main tool of anticyclical monetary policy. The challenging task of estimating natural interest rate consists of filtering cyclical higher frequency factors.

There are several different methods for estimating the real natural interest rate. Each model has its pros and cons. The first group of models builds on pure statistical filtering apart from economic theory (e. g. Hodrick-Prescott) or various state-space Kalman filter representations (e. g. Bencik, 2009). Kalman algorithm is a multidimensional filter with unobserved variables of neutral interest rate corresponding to a state where inflation equals the target, and the actual product equals the potential product. Despite the relative popularity of state-space modelling, results substantially depend on arbitrary calibrated parameters (standard deviation, etc.).

Another way of estimating the natural interest rate is the use of structural models. This approach is described for instance in Hlédik and Vlček (2018) in the case of Czech economy. The use of the structural model makes it possible to work with model- 
consistent anticipatory expectations, and the methodology of natural interest rate identification is thus more immune to Lucas's critique.

The third approach steaming from Taylor rule (Taylor, 1993) is based on economic theory. This method assumes that the Taylor rule gives an unbiased estimate of the policy response of the central bank so that the average of the residual terms is zero (Archibald et al., 2001). To reach zero average of residuals (the residual term picks up the difference between nominal interest rate implied by the Taylor rule and the behaviour of the nominal interest rate over history), the sufficiently long period of moving averages covering upward and downward phase of economic cycle must be selected.

The last group of natural interest rate estimates is tied to development of productivity (production method). Neoclassical economic theory assumes that potential growth increases returns of capital and thus natural interest rate. Carlstrom et al. (2016) suggest that natural rate of interest is equal to its initial value plus productivity growth. This method is relatively simple and intuitive, but assumes co-movement of labour and capital productivities, since the productivity is represented by total factor productivity or potential product, but only capital productivity affects the rate of return. Any shift in factor relative productivity, which is not uncommon, distorts the estimate results. The production method estimation of natural rate of interest is oriented to large closed economy. Laubach and Williams (2003) use production approach for small open economy but adjust for real equilibrium exchange rate appreciation. On the contrary Archibald et al. (2001) suggest estimating natural interest rate for foreign large economy and adding interest rate risk premium for small one. Carrillo et al. (2017) to this approach also incorporate interest rate differential and exchange rate change building on uncovered interest rate parity theory.

Incorporating exchange rate development takes into account the freedom of financial flows and the involvement of a small open economy in the global financial system. The real return on foreign investment is influenced not only by the productivity of capital in the domestic economy but also by the change in the real exchange rate. The appreciation of the exchange rate gives the foreign investor additional yield over the marginal product of the capital, which affects the natural interest rate. Therefore, if the small open economy grows rapidly and this growth is accompanied by a real appreciation of the currency, the natural interest rate is lower than the potential growth, namely, this valuation (appreciation) of the real exchange rate. The real appreciation of the exchange rate is usually accompanied by real economic growth, resulting in more stable development of natural interest rate in a small open economy compared to the closed economy. Whilst in the closed economy, the real interest rate level is determined only by the growth of the productivity (or potential output), in the open economy it is necessary to take into account, also the appreciation of the equilibrium exchange rate.

The text below develops the Taylor and production approach to fit the small open economy. Estimates of real natural rate of interest are applied to the data of Czech economy. Equation (1) shows extended Taylor rule (TR) interest rate with $\mu$ coefficient of monetary policy persistence since immediate reaction of central bank interest rate on every shock is not desirable and even not based on evidence. Thus, the optimal countercyclical monetary policy interest rate is given by its lagged values $I R_{T-1}^{C B}$, real natural interest rate $R I R_{\text {nat }}$, actual consumer price index inflation $C P I$, deviation of actual inflation 
from inflation target $C P I_{g a p}$, deviation of actual real product from potential product, i. e. output gap $O G$, deviation of real exchange rate from its equilibrium $R E R_{\text {gap }}$ (positive $R E R_{\text {gap }}$ means currency appreciated above its equilibrium value and thus creates deflationary pressures), risk premium on money market $R P_{I R}(2 \mathrm{~W}$ money market interest rate minus $2 \mathrm{~W}$ central bank reference interest rate; risk premium pushes economy under its potential) and deviation of real estate prices from its trend assets $_{\text {gap }}$ (builds on the experience from Great World Recession, where the real estate market overheating was leading indicator to the business cycle).

$$
\begin{gathered}
\text { Taylor IR }=\mu\left(I R_{T-1}^{C B}\right)+(1-\mu)\left[R I R_{\text {nat }}+C P I+\alpha\left(C P I_{\text {gap }}\right)+\beta(O G)-\right. \\
\left.\gamma\left(R E R_{\text {gap }}\right)-\sigma\left(R P_{I R}\right)+\delta\left(\text { assets }_{\text {gap }}\right)\right]
\end{gathered}
$$

Parameter $\alpha$ measures the response of the central bank interest rate to the deviation of actual inflation from the inflation target. The "Taylor principle" of pushing inflation back to target holds because of actual inflation in equation and is thus ensured by $\alpha>0$.

Taylor rule might be forward-looking with leading explanatory variables, but it does not make value-added for the sake of estimating the real natural interest rate $R I R_{\text {nat }}$, since it raises issue regarding selecting forecasted variables and moreover results are averaged, see below.

The deviation of real exchange rate from its equilibrium captures reaction to the external environment. Monetary policy in the small open economy is substantially influenced by foreign monetary policy. If there is a need for different monetary policy, the interest rate adjustment might be diminished by exchange rate channel due to interest rate differential. For instance, Czech economy showed signs of overheating in 2017, whereas growth in the Eurozone was still sluggish, and economy could be found slightly under its potential. The rise of interest rates in the Czech Republic created interest rate differential and thus appreciated currency. Therefore sustainable real interest rates could be under its natural levels with stronger exchange rate as a compensating factor.

Figure 1 shows the development of interest rates proposed by TR compared to the Czech National Bank reference monetary policy 2W REPO rate. Calibrations based on theoretical optimal working of TR with coefficients presented in Table 2 are applied. Taylor interest rate is computed on CPI, monetary policy CPI (CPI adjusted for the primary impact of changes to indirect taxes), and core CPI (monetary policy CPI without regulatory prices, food, beverages, and oil changes). For estimating natural rate of interest, we select monetary policy CPI because total CPI is affected by one-off tax effects, and core inflation is available in relatively short time series. Taylor rule suggests easier monetary policy between 2009 and 2013. During next two and half year CNB interest rates were in line with TR recommendation. For 2017 and 2018 TR proposes tighter monetary policy. 
Figure 1. Taylor rule interest rates (theory calibrations)

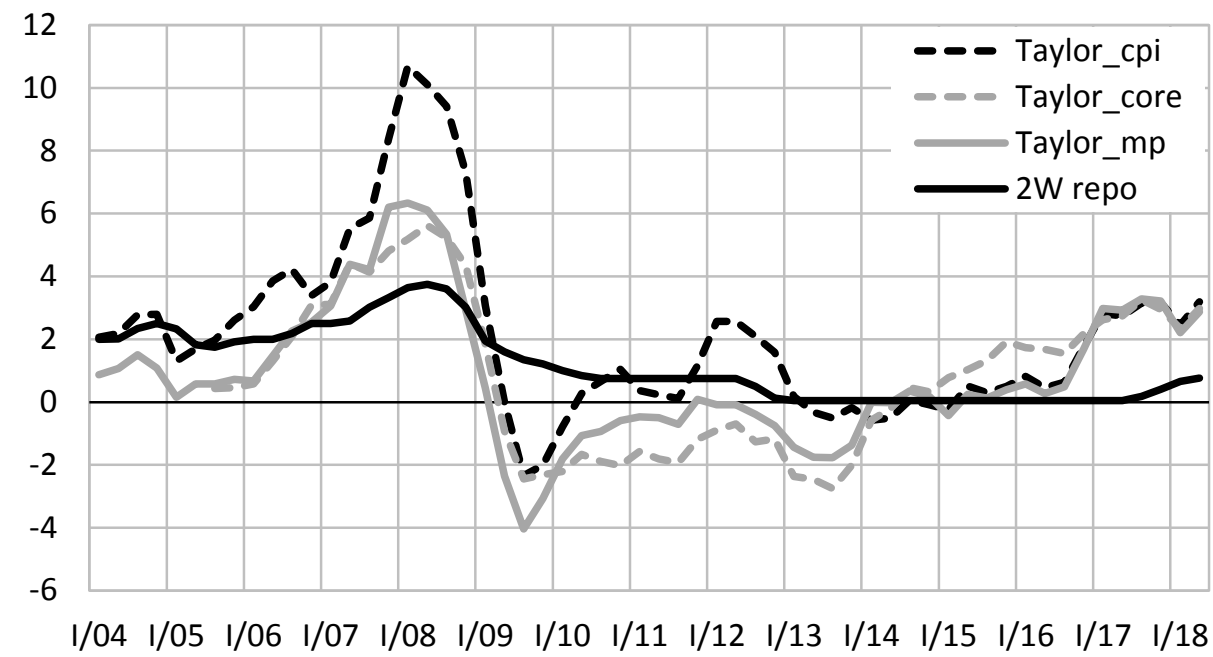

Source: own calculations, Czech National Bank.

The decomposition of the TR interest rate with monetary policy CPI and coefficients calibrations ensuring optimal countercyclical monetary policy reactions is presented in Figure 2. The increase of interest rates has been proposed since the end of 2016 strongly driven by high pace of real estate prices.

Figure 2. Contributions to the Taylor rule interest rate (theory calibrations)

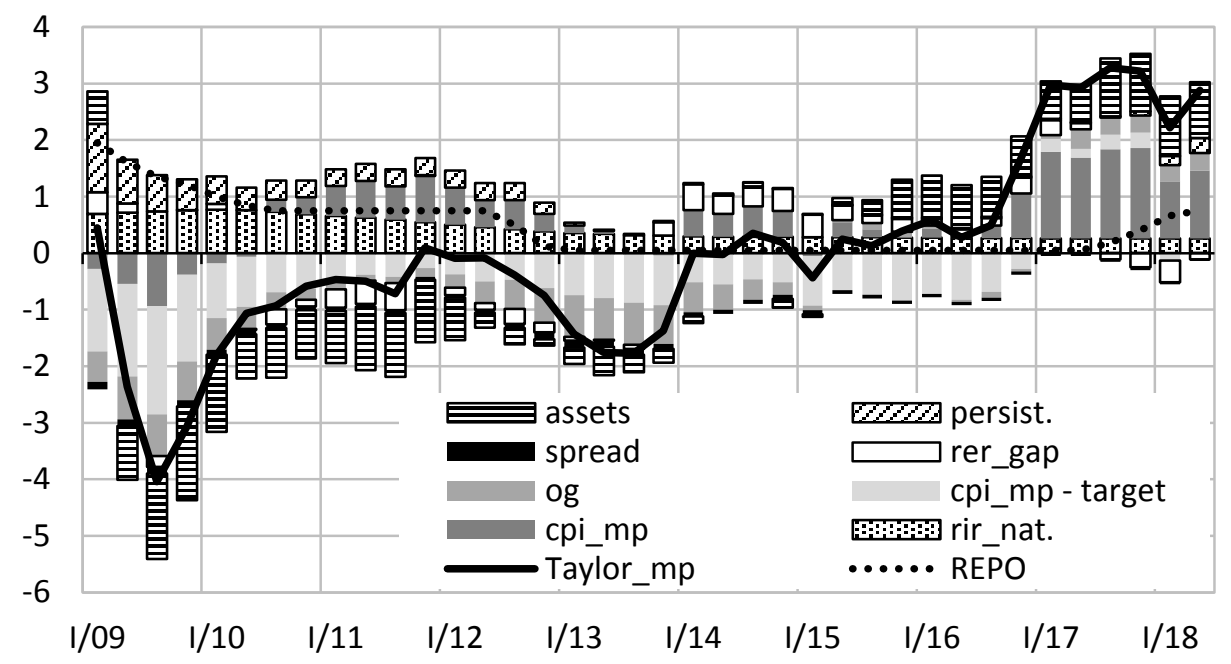

Source: own calculations, Czech National Bank. 
Table 1 shows variables with descriptive statistics used in the models below. Quarterly data from the Czech National Bank, Eurostat, Ministry of Finance, and Czech Statistical office are used from 1998 till the second quarter of 2018. The output gap is calculated by production function approach from MF CR (2018). Real exchange and interest rate gaps are deviations of actual values from its equilibrium levels calculated below. The asset prices gap is a deviation of offered flat prices from CNB inflation target plus 2 p. p. (long term average of real convergence of Czech economy to the Eurozone). The real exchange rate is in EUR/ CZK, base indexes of GDP deflators $(2015=100)$ of Czech Republic and Eurozone were used to calculate real exchange rates from nominal ones. The productivity of Czech economy is defined as GDP per worker as a percentage of euro area in purchasing power standard. Net foreign assets are net investment position as a percentage of GDP in current prices. Terms of Trade relative to Eurozone are calculated as price of exports over price of imports. Gross Fixed Capital Formation as a percentage of GDP in current prices reflects the share of investment in GDP. Gross savings are as a percentage of GDP.

Table 1. Data description

\begin{tabular}{llllll} 
Variable & Abbreviation & Mean & $\begin{array}{l}\text { Standard } \\
\text { deviation }\end{array}$ & Jarque-Bera & ADF test \\
\hline YoY Monetary policy-relevant CPI & CPI & 1,07 & 1,35 & $60,22^{* * *}$ & $-2,71^{*}$ \\
Monetary policy-relevant CPI gap & CPI gap & $-1,95$ & 1,30 & 0,47 & $-4,19^{* * *}$ \\
Output gap & OG & $-0,54$ & 2,18 & 3,05 & $-3,18^{* *}$ \\
Real exchange rate gap & RER $_{\text {gap }}$ & $-0,06$ & 3,09 & $33,69^{* * *}$ & $-4,933^{\star * *}$ \\
Real interest rate gap & RIR $_{\text {gap }}$ & $-0,04$ & 1,62 & 1,89 & $-4,28^{\star * *}$ \\
Interest rate risk premium & RP $_{\text {IR }}$ & 0,08 & 0,07 & $44,99^{* * *}$ & $-4,52^{\star * *}$ \\
Asset prices gap & assets & 2,09 & 8,84 & 1,57 & $-2,88^{*}$ \\
CNB 2W REPO interest rate & IR & 2,63 & 3,23 & $168,75^{* * *}$ & $-6,22^{* * *}$ \\
Real exchange rate (EUR/CZK) & RER & 0.0364 & 0.0032 & $5.62^{* *}$ & -1.94 \\
Productivity & PROD & 0.68 & 0.04 & $14.98^{* * *}$ & -2.36 \\
Net foreign assets & NFA & -30.57 & 11.59 & 3.99 & -1.86 \\
Terms of trade & TOT & 0.99 & 0.02 & 1.92 & $-2.82^{*}$ \\
Gross fixed capital formation & FCF & 27.20 & 1.85 & 3.25 & $-2.84^{*}$ \\
Gross Savings & SAV & 25.15 & 2.20 & 5.27 & -2.50
\end{tabular}

Source: own calculations, Czech National Bank, Eurostat, Ministry of Finance, Czech Statistical Office.

Note: Jarque-Bera statistic under the null of normal distribution. ADF is an augmented DickeyFuller statistic under the null of unit root. *,**,*** denote rejection of the null at $10 \%, 5 \%$ and $1 \%$ level of significance, respectively.

The real natural rate of interest is derived in equation (2) from TR with replacement of TR interest rate for actual central bank interest rate $I R^{C B}$. The resulted real natural interest rate $R I R_{\text {nat }}$ is ten year moving average, which is sufficiently long period covering upward and downward phase of economic cycle to reach unbiased residuals. 


$$
\begin{gathered}
R I R_{\text {nat }}=\left[I R^{C B}-\mu\left(I R_{T-1}^{C B}\right)-(1-\mu)\left(C P I+\alpha\left(C P I_{\text {gap }}\right)+\beta(O G)-\gamma\left(R E R_{\text {gap }}\right)-\right.\right. \\
\left.\left.\sigma\left(R P_{I R}\right)+\delta\left(\text { assets }_{\text {gap }}\right)\right)\right] /(1-\mu)
\end{gathered}
$$

For calibration weights, we use the coefficients presented in Table 2. CZ Taylor_theory represents theoretical calibration ensuring optimal countercyclical response of monetary policy. CZ Taylor_OLS is based on regression estimate presented in equation (3) conducted by ordinary least square method.

$$
\begin{array}{r}
d\left(I R^{C B}\right)=0,11 C P I_{g a p}+0,04 O G-0,05 R E R_{g a p}+0,61 d\left(I R_{T-1}^{C B}\right)^{3} \\
(0,024)^{* * *}(0,025)^{*} \quad(0,017)^{* * *} \quad(0,089)^{* * *}
\end{array}
$$

The third CZ Taylor_GRG model is an alternative GRG (Generalized Reduced Gradient) method, which is generalization of the reduced gradient method by allowing nonlinear constraints and arbitrary bounds on the variables, and it is widely used for solving nonlinear optimization problems. GRG method has been applied by tool Solver in MS Excel. OLS and GRG approaches capture the historical reaction function of CNB, whilst theoretical calibration represents a hypothetical optimal monetary policy setting.

Table 2. Taylor equation parameters

\begin{tabular}{llcccc} 
Parameter & & CZ Taylor_theory & CZ Taylor_OLS & CZ Taylor_GRG & EA Taylor_theory \\
\hline$\alpha$ & CPI gap & 0,70 & 0,11 & 0,27 & 0,70 \\
$\beta$ & output gap & 0,30 & 0,04 & 0,47 & 0,30 \\
$\gamma$ & RER gap & 0,20 & 0,05 & 0,18 & $\cdot$ \\
$\sigma$ & IR risk & 1,00 & 0,00 & 1,05 & $\cdot$ \\
$\delta$ & premium & & & 0,00 & $\cdot$ \\
$\mu$ & assets & 0,20 & 0,00 & 0,93 & 0,40 \\
\hline
\end{tabular}

Source: own calculations.

Figure 3 represents real natural interest rate estimates on Taylor approach compared with the HP filter with for quarterly series recommended lambda 1600 and HP filter with the same lambda anchored to $0,4 \% \mathrm{p}$. a. at the end of the time series. An alternative approach for small open economy is also presented by computing real natural interest rates for Eurozone with theory calibration (EA Taylor_theory in Table 2). It is assumed that small open economy might be price taker in case of real interest rate (Archibald et al., 2001). This approach is further modified by adding relative risk premium (Czech natural interest rates are equal to EA natural interest rates plus Czech relative risk premium), which is approximated as follows:

\footnotetext{
${ }^{3} \mathrm{R}^{2}=0,57 ; \quad$ Durbin- $\mathrm{h}=0,17 ; \quad \mathrm{p}(\mathrm{F})=0,00 ; \quad \mathrm{N}=80$.
}

Values in the brackets represent standard error of mean. *, **, *** denote rejection of the null at $10 \%, 5 \%$ and $1 \%$ level of significance, respectively, under null of zero regression coefficient. 


$$
R P=\frac{10 Y C Z \text { gov.bond }-C N B \text { interest rates }}{10 Y E A \text { gov.bond }-E C B \text { interest rates }}
$$

The last estimate further incorporates an uncovered real interest rate parity (UIRP) equation (5). Expected exchange rate $E\left(R E R^{\frac{C Z K}{E U R}}\right)$ is approximated as change of equilibrium real exchange rate (in chapter 2). Appreciation of CZK koruna to euro currency thus diminishes Czech interest rates compared to Euro area.

$$
\left(1+R I R^{C Z}\right)=\frac{E\left(R E R^{\frac{C Z K}{E U R}}\right)}{R E R^{\frac{C Z K}{E U R}}}\left(1+R I R^{e a}+R P\right)
$$

The most estimates confirm a downward trend in natural rate of interest, but the estimate range is approximately $2 \mathrm{p}$. p. We take into account specific period of the Great World Recession, which might distort Taylor based estimates due to prolonged time of economic recession and easy monetary conditions. The assumption of symmetric cycle in sufficiently long smoothing (10-year moving average; longer is not possible due to availability of data) period might be broken. Therefore the upper estimate (CZ Taylor_theory), which is in line with anchored H-P filter for the last 5 years, might be reasonable estimate of natural interest rate in the Czech Republic.

Figure 3. Real natural interest rate estimates - Taylor approach + H-P filter

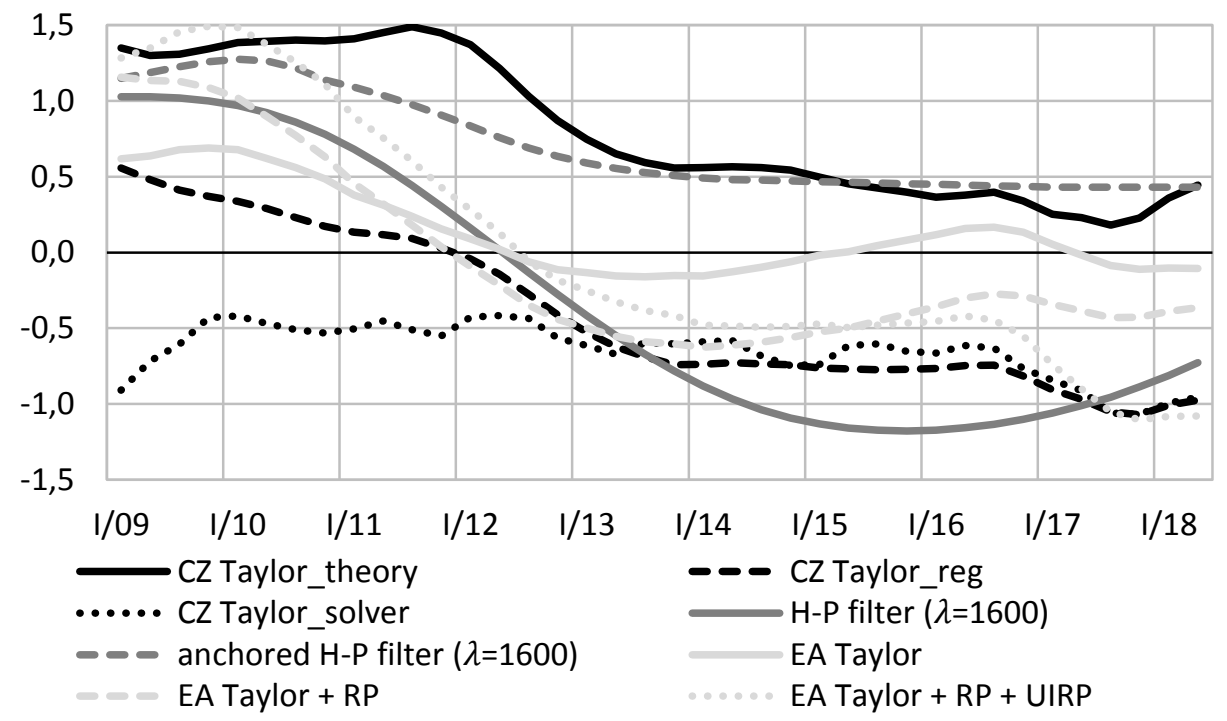

Source: own calculations.

Figure 4 shows the development of real natural interest rate estimated by production approach, which is the sum of potential product growth (MF CR, 2018) and rate of equilibrium real exchange rate appreciation (appreciation diminishes natural interest rate and vice versa; estimate from following Chapter were used). Unlike in world economy, production approach captures increase of natural interest rate between 2011 and 
2013. But its endpoint value is close to preferred Taylor based model (CZ Taylor_theory in Figure 3).

Figure 4. Real natural interest rate estimate - production approach

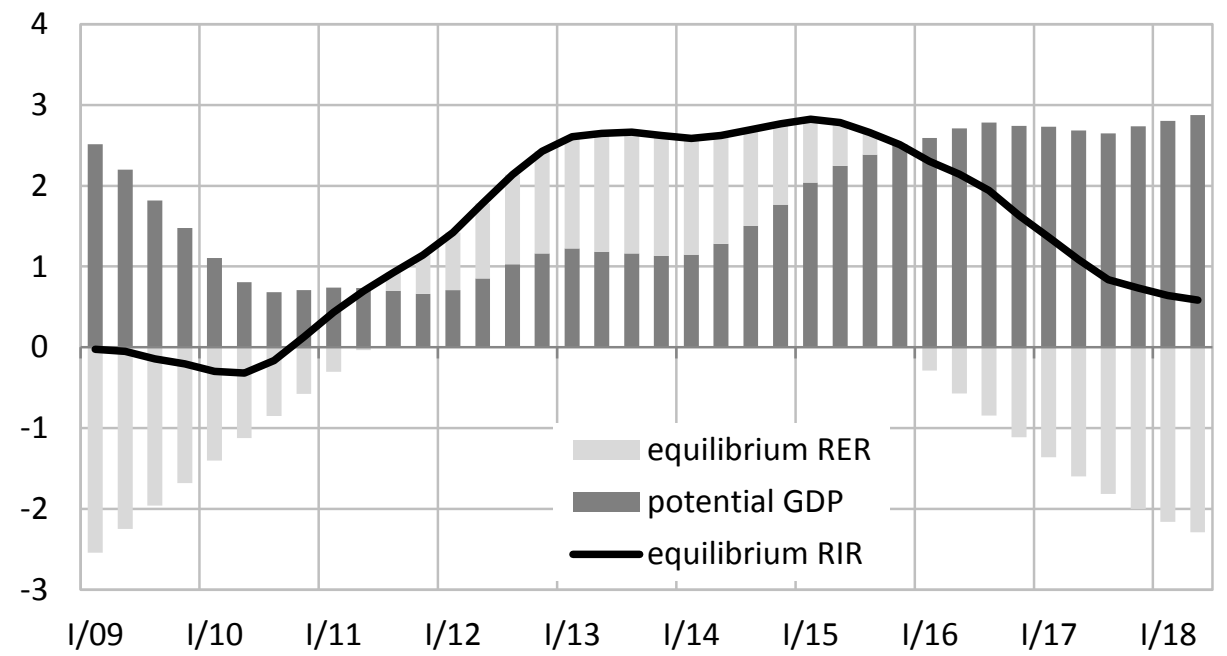

Source: Ministry of Finance CR (2018), own calculations.

In the context of the slowdown in real economic growth after the Great World Recession, most estimates suggest a decline in natural interest rates in developed countries after 2008. The economic reason for the relatively steep decline in natural interest rates from 2010 to 2012 might be higher savings and deleveraging pressures, especially in Europe (austerity measures in PIGS countries, budget surpluses in Germany, etc.) accompanied by weaker pace of global capital productivity compared to pre-crisis period.

Holston et al. (2017) estimate that the natural rate has fallen in the US, Canada and the Eurozone after the global financial crisis by 1,5 p. p. With the economic recovery, the natural rate is stabilized at low levels (US and Canadian estimate) or returns above zero, as in the case of the euro area. The current level for the US and the Eurozone is estimated at between 0 and 0,5 percent. Similar values and a renewed moderate increase in the natural interest rate in the euro area are also suggested by Fries et al. (2016) or Brand et al. (2018). Thus, the level and trend of natural rate of interest in the Czech Republic in 2018 according to selected Taylor rule-based model applied in this article are close to the world values, which is reasonable for small and open economy.

\section{Equilibrium real exchange rate}

The level of real exchange rate determined by economic fundamentals is referred to as equilibrium. Unlike nominal exchange rate the equilibrium real exchange rate (ERER) is unobserved and uneasy to estimate variable. In order to assess its values it is necessary to employ economic theory and statistical methods leading to non-identical equilibria dependent on the method used. Yet, it plays an important role both in macroeconom- 
ic theory and policy. Possible deviations of the observed exchange rate from ERER are one of the key factors for setting of primary interest rates of central bank.

Long term development of real exchange rate is often described by Purchasing Power Parity (PPP), which builds on neoclassical law of one price and implicates constant real exchange rate. All deviations from PPP are inevitably interpreted as deviations from equilibrium. Therefore this concept is not suitable in the world of long term convergence, real shocks, and capital flows (Komárek, Motl, 2012). The inapplicability of absolute or relative PPP concept on Czech crown is supported, among others by Babetskii and Balasz (2005).

Ballasa-Samuelson (BS) effect attempts to explain persistent currency appreciation trends present among emerging and transition economies. Productivity growth and its differences not only among countries but also in tradable and non-tradable sectors lead through wage adjustment to differences in price levels between these sectors, which then influence the real exchange rates (Holub and Čihák, 2003).

Various models have been constructed and estimated to capture and describe determinants of ERER. In general, economic models can be divided into normative, which state the desired outcome and calculate the trajectory to reach it from the current state, and positive which calculate further developments based on current and past observed results.

Fundamental Equilibrium Exchange Rate (FEER) is the basic normative concept. The cornerstone of the FEER model is intentionally omitting short term cyclical or temporary factors and focusing on fundamental factors dominating in the medium- to longterm. It is a multi-equation approach with resulting ERER being consistent with internal and external equilibrium of the economy. Internal equilibrium is often defined as the level of output consistent with full employment (resp. natural rate of unemployment) and low-level sustainable inflation. External equilibrium is described by balance on the current account. It is a normative concept in explicitly estimating sustainable fiscal policy given full employment and setting goals for current account. Mathematical derivation of FEER can be found for example in Frait and Komárek (1999), application on exchange rate of Czech koruna in Komárek and Motl (2012).

Positive concepts aim to estimate equilibrium based on historical values and policies currently in place. Behavioral Equilibrium Exchange Rate (BEER) is based on uncovered interest rate parity. RER depends on the terms of trade, the ratio of non-tradable to tradable prices (BS effect), and the net foreign assets (Horváth and Komárek, 2006). Second commonly used positive concept is Natural Equilibrium Exchange Rate (NATREX), which determines RER based on fundamental factors that determine the flow of capital in medium to long term. These factors can be for example savings, investments, productivity, net foreign assets, terms of trade, or world interest rate.

Komárek and Motl (2012) classified the methods of finding ERER into the following (a) trend lines and statistical filters, (b) unit root tests and cointegration analysis, and (c) structurally rich models. The following paragraphs provide brief overview of the methods.

Purely statistical approaches to ERER are trend lines and filters. Commonly used are the Hodrick-Prescott filter (HP filter) or Band-Pass filter (BP filter), which has 
the advantage of distinguishing between cyclical and non-cyclical components. Statistically more advanced is Kalman filter whose both advantage and disadvantage is the possibility to choose multiple specifications with great influence on the result.

Unit root tests and cointegration are used to first identify nonstationary time series and secondly to describe their long term relationship. In this context, equilibrium is a state towards which the whole system tends to return (Engle and Granger, 1987). This concept is often used to identify explosive components, including possible bubbles, and is the basis for the BEER approach.

Technically most advanced are the structurally rich models which estimate the equilibrium exchange rate usually through supply and demand factors. This approach is used by Bruha and Tonner (2017) to estimate the real exchange rate of Czech koruna and other macroeconomic variables under various monetary policy scenarios.

\section{Equilibrium real exchange rate of the Czech crown}

Based on the existing literature, following variables were preselected as medium to long term factors influencing the ERER. A detailed discussion of the effects of presented variables can be found among others in Frait and Komárek (1999), Babetskii and Balasz (2005), or Komárek and Melecký (2005) who also present overview of empirical findings.

A higher productivity (PROD) is expected to result in the appreciation of Czech crown, which is indeed the overwhelming finding in literature (Komárek and Melecký, 2005). This channel is traditionally associated with the BallassaSamuelson effect.

Empirical findings do not agree on the clear direction of the effect of net foreign assets (NFA) on RER (Komárek and Melecký, 2005); method used, time span, and variables included in the analysis play role. According to Rogoff and Stavrakeva (2008) the effect of NFA on the currency of transition or emerging economy changes along with the transformation of the economy. First the increase in net foreign assets can lead to appreciation because of the inflow of foreign investment and later to depreciation because of the outflow of dividends and rental payments.

An increase in terms of trade (TOT), an increase in prices of exported goods, will generate two effects. A substitution effect, where the domestic producers shift towards exportable (tradable) goods, results in higher wages in tradable sector. Wages then equalize through labour mobility, increasing domestic price level. The substitution effect leads to appreciation of domestic currency. In the opposite direction pushes the income effect which improves the trade balance, raises the income of domestic economy and generates higher demand for non-tradable goods. In empirical results, the income effect leading to depreciation dominates (Komárek and Melecký, 2005).

We also included in our analysis gross fixed capital formation (GFCF) and gross savings (SAV) as a percentage of GDP. Their effect is rather long term, and evidence on the direction of the effect is mixed (Komárek and Melecký, 2005). 
When developing each model we proceeded according to the following methodology. Because we are interested in long-run trends and equilibria all variables were seasonally adjusted (using X-13 procedure in EViews). Then we tested for stationarity using Augmented Dickey-Fuller test on levels (results can be found in Table 1) and differences. Variables RER, PROD, NFA, SAV were integrated of order one, I(1); GFCF and TOT were integrated of order zero, I(0), stationary. We then created various VAR models with I(1) variables as endogenous and $\mathrm{I}(0)$ as exogenous variables (Table 3); lag length tests were carried out to decide on suitable number of lags. Then we used the Johansen cointegration test to find out whether their linear combination that is stationary exists. This would ensure that deviations from equilibrium are temporary, in other words variables are pulled towards their equilibrium values and VECM could be used. The error-correction relates to the fact that last periods' deviations from long-run equilibria affect short-run dynamics.

Quarterly data from 1Q 2001 to 2Q 2018 were used to estimate the VECMs. In Table 3 standard model evaluation statistics are presented.

Table 3. Model evaluation statistics

\begin{tabular}{rlcccc} 
Model & \multicolumn{1}{c}{ Variables } & $\begin{array}{c}\text { R- } \\
\text { squared }\end{array}$ & $\begin{array}{c}\text { Log } \\
\text { likelihood }\end{array}$ & $\begin{array}{c}\text { Akaike infor- } \\
\text { mation criterion }\end{array}$ & Schwarz criterion \\
\hline VECM 1 & PROD, NFA & 0,41 & 548,56 & $-15,38$ & $-14,80$ \\
VECM 2 & PROD & 0,40 & 676,42 & $-19,32$ & $-18,99$ \\
VECM 3 & PROD, NFA, SAV & 0,34 & 414,11 & $-11,19$ & $-10,28$ \\
VECM 4 & PROD, NFA, GFCF & 0,28 & 481,92 & $-13,16$ & $-12,25$ \\
VECM 5 & PROD, NFA, GFCF, SAV & 0,37 & 349,16 & $-8,96$ & $-7,67$ \\
VECM 6 & PROD, NFA, TOT & 0,43 & 539,78 & $-15,26$ & $-14,57$ \\
\hline
\end{tabular}

Source: own calculations.

Based on Table 3 we chose VECM 1, 2 and 6 for further evaluation. Results from dismissed models were pointing on structural long term under- or over-valued exchange rate which is inconsistent not only with literature but also with effective forex markets. When looking closer on VECM 6, TOT is according to Augmented Dickey-Fuller test stationary and therefore was used as an exogenous variable. Although model with PROD and NFA as endogenous and TOT as exogenous variable has relatively good statistics, TOT is itself statistically not significant and therefore does not influence the result.

Therefore the coefficients estimated through VECM 1 and 2 were used to calculate the single equation ERER. In Figure 5 we can see the graphical representation of the results; HP filter is for visual comparison and a check of results adequacy. For calculating the monetary conditions index we will use the average of the two ERERs weighted by respective standard deviations. 
Figure 5. Equlibrium real exchange rate estimates (CZK/EUR)

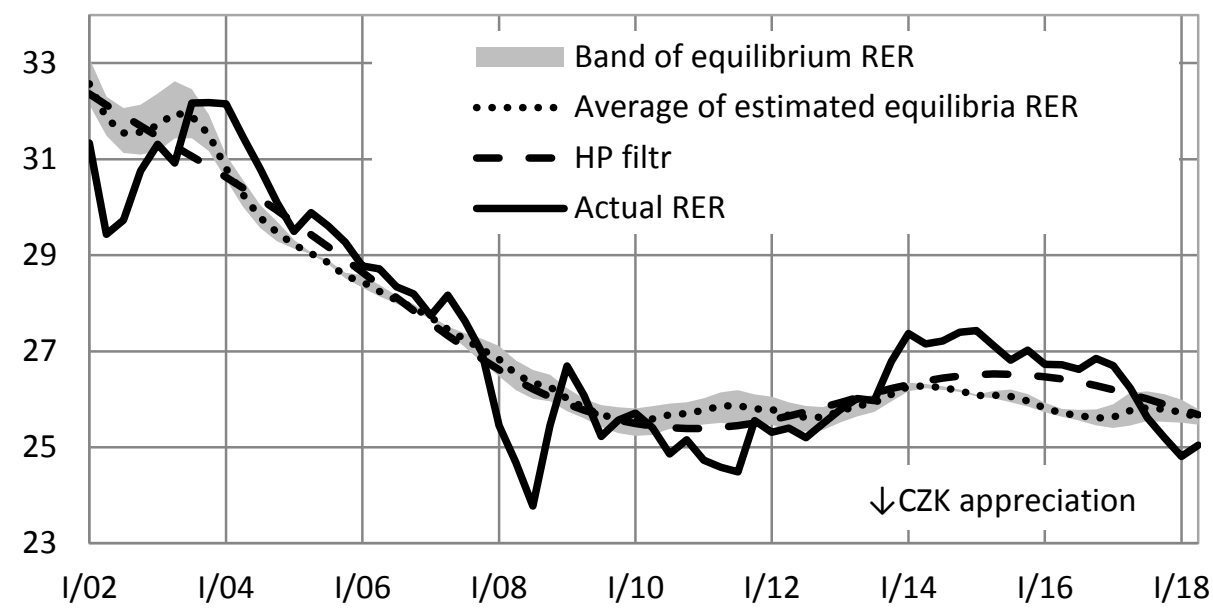

Source: own calculations, Czech National Bank, Eurostat.

Calculated ERER of Czech crown was continuously strengthening from 2004 to 2009. The year 2010 marked the start of ERER stagnation, which was present until the year 2018. Main cause of this development is the quick productivity growth relative to euro area and its stagnation from 2009 to 2014. This general result is in line with the results of Komárek and Motl $(2005,2018)$.

Looking at the calculated ERER, we can see periods of actual RER being very close to equilibrium and periods of misalignments between actual and equilibrium values. Noteworthy is the time period in late 2007 and early 2008 when Czech crown went through the period of rapid stronger than equilibrium strengthening that can be associated with overheating economy, maturing economic cycle, and excessive optimism. Such development was then corrected in the year 2009 through weakening of Czech crown, and the exchange rate returned near-equilibrium values. Stronger than equilibrium values through 2011 to mid-2013 acted against the easing of monetary conditions and slowed down the recovery of whole economy (Komárek and Motl, 2018). The period of CNB's interventions from 4Q 2013 to 2Q 2017 is marked by prolonged period of weaker than equilibrium crown. Unlike Komárek and Motl (2018) who find weaker than equilibrium nominal crown in 2015, we see it already in 2014. Also the evolution after the interventions ceased is perceived slightly differently. Komárek and Motl (2018) find the actual exchange rate to be very close to equilibrium; we on the other hand see it stronger than equilibrium.

\section{Monetary conditions index}

The monetary conditions index is composed of the weighted sum of changes in real interest rates and changes in the real exchange rate. The key issue is the choice of short or long-term interest rates, price deflators, exchange rates, and relative weights. Discussion about the appropriate options is available in Pfeifer and Pikhart (2015). Based on that findings we use short-term 1M PRIBOR interbank interest rates and EUR/CZK 
exchange rate when calculating the monetary conditions index (both deflated by GDP deflator) since euro transactions in the Czech Republic form the majority of foreign currency transactions due to the close trade and financial interlinkages. We use the implicit GDP deflators since the GDP deflator corresponds to the definition of the real exchange rate as an indicator of the relative purchasing power of the domestic currency relative to foreign and domestic output. The problem of nominal convergence, embodied in the long-term strengthening of the real exchange rate, is solved by calculating the percentage deviations from the equilibrium values (and percentage points deviations in terms of real interest rate gaps). Deflating ex-post is standardly used since there is insufficient reliable series of inflation expectations for a representative range of economic subjects.

Figure 6 shows the evolution of equilibrium and observed real interest rates and the real exchange rate. The selected model estimates presented in previous chapters were used as the natural values. In the period just before the start of the foreign exchange intervention in November 2013, the equilibrium real exchange rate had corresponded to roughly equilibrium exchange rate values. During FX interventions from the end of 2013 till the first quarter of 2017, the exchange rate had been in the clear under-valuated area. Since resuming the free-floating the exchange rates have sharply appreciated and even overshoot its equilibrium values, which might explain sluggish appreciation in the near future.

For weighing, we use a least squares regression estimate with explained output gap variable and explanatory variables in the form of delayed real interest rate spreads and real exchange rates from equilibrium levels and delayed values of output gap itself. The regression coefficients in the equation below are statistically significant and give an intuitive sign. The highest correlation between the output gap and the real interest rate gap is in advance of five quarters. For the real exchange gap, the strongest transmission is observed at four quarters ahead of the output.

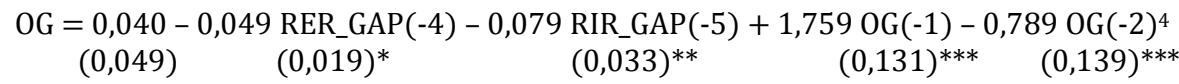

\footnotetext{
${ }^{4} \mathrm{R}^{2}=0,90 ; \quad$ Durbin- $\mathrm{h}=0,15 ; \quad \mathrm{p}(\mathrm{F})=0,00 ; \quad \mathrm{N}=72$.

Values in the brackets represent standard error of mean. *, **, *** denote rejection of the null at $10 \%, 5 \%$ and $1 \%$ level of significance, respectively, under null of zero regression coefficient.
} 
Figure 6. Deviations of real interest rates and real exchange rate from its natural levels
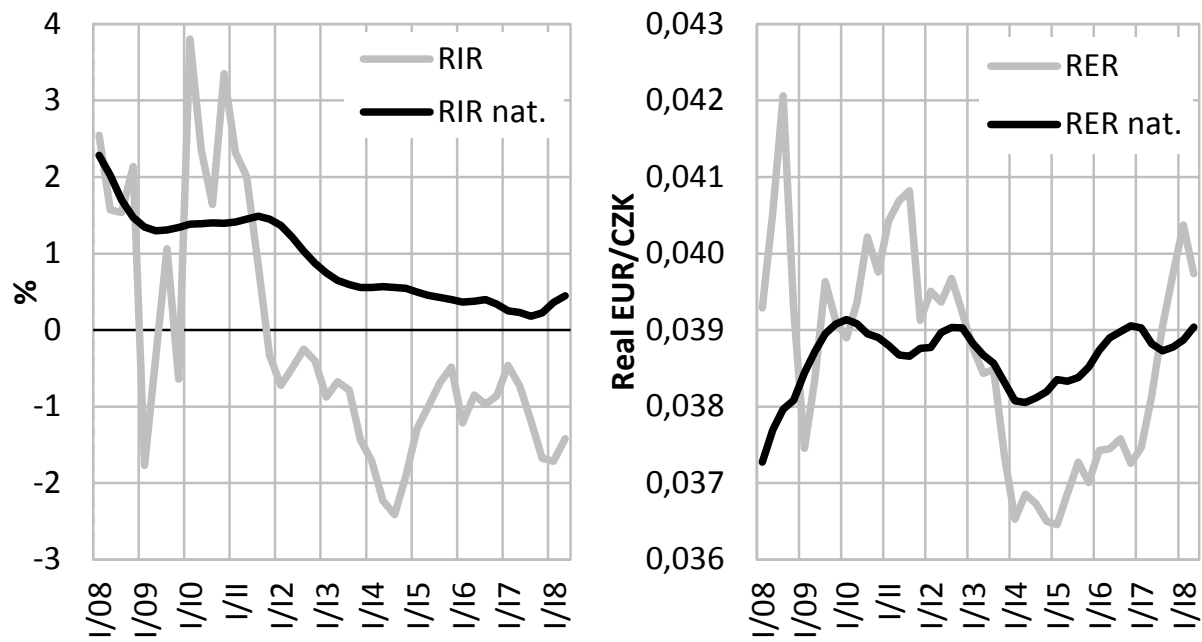

Source: own calculations, Czech National Bank.

In order to eliminate heteroskedasticity, the standard deviation was explained by the delayed value of its residua (ARCH model). The coefficient is statistically significant.

$$
\begin{aligned}
\sigma^{2}= & 0,119+0,533 \varepsilon_{\mathrm{t}-1}^{2} \\
& (0,031)^{* * *}(0,301)^{* *}
\end{aligned}
$$

If we use the above-mentioned regression coefficients for real interest and exchange rate gaps and normalize. We get a ratio of 0.38 to 0.62 in favor of the real interest rate gap. The weights used are, therefore, at the top edge of the most frequently applied balances for small open economies.

$$
\text { MCI }=0,38 \text { RER_GAP }+0,62 \text { RIR_GAP }
$$

Figure 7 shows a calculated monetary conditions index in the Czech Republic broken divided into the interest and exchange rate components. The picture shows a significant influence of the exchange rate component on the development of the Czech monetary conditions index, where the appreciation of the exchange rate above trend (positive values) leads to a tightening of monetary conditions and vice versa. In 2014, there was a noticeable easing of monetary conditions due to foreign exchange intervention to weaken the currency in November 2013. Since the beginning of 2017 and resumed freefloating of currency the exchange rate has been appreciating, and monetary conditions have shifted from loose to almost neutral in the first quarter of 2018. 


\section{Figure 7. Monetary conditions index}

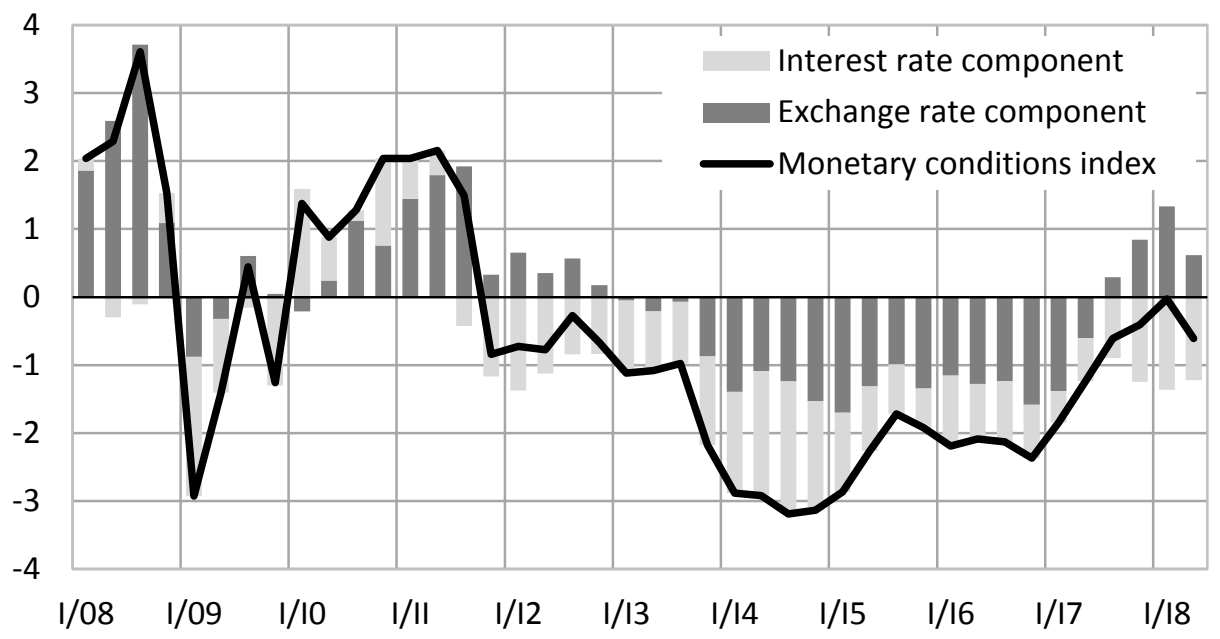

Source: own calculations.

\section{Conclusion}

Our paper captures the monetary policy stance in both of its traditional tools: interest rates and exchange rate. Despite the fact that equilibrium values and deviations from them are, in this case, unobservable they are crucial for the monetary policy and its appropriate anticyclical settings.

There are several methods of estimating the natural rate of interest available with specific advantages and disadvantages. We adapted Taylor rule-based approach to conditions of small and open economy, which produces very reasonable estimates of Czech natural rate of interest. Most of the estimates point to a significant decline in natural rate of interest since 2010 .

Equilibrium real exchange rate was assessed through VECM model, where productivity and net foreign assets were key variables. The general course of the equilibrium exchange rate path is in line with relevant literature, although some differences can be found, especially at the beginning of exchange rate interventions and after their end.

Both unobservable components - interest rate gap and exchange rate gap from its equilibrium values - are crucial for the construction of the monetary conditions index, which is presented in the last chapter. The weight of both components in the MCI index was assigned based on their explanatory power in the output gap regression, where after normalisation the interest rate gap accounts for $2 / 3$ and exchange rate gap for $1 / 3$ of MCI.

In this article we developed a methodology to obtain MCI, a single gap index that captures the monetary conditions. Periods of loose and tight monetary policy can be easily identified along with the share of interest rate and exchange rate influence and help with central banker's decision making. Future verifications of models validity are necessary 
to reduce the uncertainty about estimated equilibrium values and the share of MCI components.

Funding: This work was supported by the Czech Science Foundation project No. 1812340S Anti-cyclical policies and external equilibrium in a model of inflation targeting. This support is gratefully acknowledged.

Disclosure statement: No potential conflict of interest was reported by the authors. The information and views set out in this article are those of the authors and do not necessarily reflect the official opinion of the Ministry of Finance.

\section{References}

ARCHIBALD, J., HUNTER, L. (2001). What is the neutral real interest rate, and how can we use it? Reserve Bank of New Zealand. Bulletin vol. 64, no. 3, pp. 15-23.

BABETSKII, I., BALAZS, E. (2005). Equilibrium Exchange rate in the Czech Republic: How good is the Czech BEER? William Davidson Institute Working Paper Number 781 .

BENCIK, M. (2009). The equilibrium interest rate - theoretical concepts and applications. Slovak National Bank. Vol. 17, no. 4, pp. 1-11.

BRAND, C., BIELECKI, M., PENALVER, A. (2018). The Natural Rate of Interest Estimates, Drivers, and Challenges for Monetary Policy. ECB Occassional Paper. Forthcoming.

BRUHA, J., TONNER J. (2017). An Exchange Rate Floor as an Instrument of Monetary Policy: An Ex-post Assessment of the Czech Experience, Working Papers 2017/04, Czech National Bank, Research Department.

CARLSTROM, C., STEHULAK, T. (2015). The Long-Run Natural Rate of Interest. Federal Reserve Bank of Cleveland. Economic trends, no. 7.

CARLSTROM, C., FUERST, T. (2016) The Natural Rate of Interest in Taylor Rules. Federal Reserve Bank of Cleveland. Economic commentary, no. 2016-01.

CARRILlO, J., ELIZONDO, R., RODRIGUEZ-PEREZ, C., ROLDAN-PENA, J. (2017) What Determines the Neutral Rate of Interest in an Emerging Economy? Banco de Mexico. Research paper, February 9, pp. 1-43.

CURDIA, F., TAMBALOTTI, A. (2015). Has U.S. Monetary Policy Tracked the Efficient Interest Rate? Journal of Monetary Economics, no. 70, pp. 72-83. DOI: 10.1016/j.jmoneco.2014.09.004

ÉGERT, B., PODPIERA, J. (2008): Structural inflation and real exchange rate appreciation in Visegrad-4 countries: Balassa-Samuelson or something else? Centre for Economic Policy Research no. 20.

ENGLE, R. F., GRANGER, C. W. J. (1987): Cointegration and Error Correction: Representation, Estimation, and Testing. Econometrica 55, pp. 251-276. DOI: $\underline{10.2307 / 1913236}$ 
FRAIT, J., KOMÁREK, L. (1999). Dlouhodobý rovnovážný reálný měnový kurz koruny a jeho determinanty. Výzkumná práce České národní banky č. 9, pp. 147-165.

FRIES, S., MESONNIER, J. S., MOUABBI, S., RENNE, J. P. (2016). National natural rates of interest and the single monetary policy in the Euro Area. Banque de France. Working Paper 611.

HLÉDIK, T., VLČEK, J. (2018). Quantifying the Natural Rate of Interest in a Small Open Economy - The Czech Case. Czech National Bank. Working Papers 2018/7.

HOLUB, T., ČIHÁK, M. (2003). Price Convergence: What Can the Balassa-Samuelson Model Tell Us? CNB WP No. 8/2003.

HORVÁT, R., KOMÁREK, L. (2006): Equilibrium Exchange Rates in EU New Members: Applicable for Setting the ERM II Central Parity?, MPRA Paper No. 1180.

HOLSTON, K., LAUBACH, T., WILLIAMS, J. C. (2017). Measuring the Natural Rate of Interest: International Trends and Determinants. Journal of International Economics. Vol. 108(S1), pp. 59-75. DOI: 10.1016/j.jinteco.2017.01.004

KOMÁREK, L., MELECKÝ, M. (2005): The Behavioral Equilibrium Exchange Rate of the Czech Koruna, CNB Working Paper Series, No. 5/2005.

KOMÁREK, L., MOTL, M. (2012). Behaviorální a fundamentální rovnovážný měnový kurz české koruny. Politická ekonomie, No. 2, pp. 147- 166. DOI: $\underline{10.18267 / j . p o l e k .835}$

KOMÁREK, L., MOTL M. (2018): Jak si vede náš měnový kurz? [online], ČNB https://www.cnb.cz/cs/o_cnb/cnblog/Jak-si-vede-nas-menovy-kurz/. Accessed 22 Jan. 2019.

LAUBAUCH, T., WILLIAMS, J. C. (2003). Measuring the Natural Rate of Interest. The Review of Economics and Statistics. No. 85, pp. 1063-1070. DOI: $\underline{10.1162 / 003465303772815934}$

MF CR (2018). Macroeconomic Forecast of the Czech Republic. Ministry of Finance of the Czech Republic. November 2018. ISSN 2533-5588.

PFEIFER, L., PIKHART, Z. (2015): Vliv měnových podmínek na jednotlivé kategorie cen v České republice v kontextu měnové a makroobezřetnostní politiky. Politická ekonomie, no. 8/2015, pp. 948-966.

ROGOFF, K. S., STAVRAKEVA, V. (2008): The Continuing Puzzle of Short Horizon Exchange Rate Forecasting, National Bureau of Economic Research Working Paper 14071 .

TAYLOR, J. (1993). Discretion versus policy rules in practice. Carnegie-Rochester Series on Public Policy. No. 39, pp. 195-214.

WICKSELL, K. (1898). Interest and Prices. Edition by Kahn, R. F., 1936. London: Macmillan. 